\title{
DIET RECONSTRUCTION OF MONKS AT ST. PETER'S MONASTERY IN OSOR: THE ROLE OF MOLLUSCS IN FOLLOWING THE RULE OF ST. BENEDICT
}

\section{MIA RIZNER}

UDC: 27-788:641(497.572)

Preliminary communication

Manuscript received: 31. 10. 2016.

Revised manuscript accepted: 07. 02. 2017.

DOI: 10.1484/J.HAM.5.113738

\author{
M. Rizner \\ Ministarstvo kulture \\ Uprava za zaštitu kulturne baštine \\ Konzervatorski odjel u Rijeci \\ Užarska 26, Rijeka, Hrvatska \\ riznermeister@gmail.com; mia.rizner@min-kulture.hr
}

A significant amount of land and marine malacofauna remains have been uncovered during the perennial excavations of St. Peter's monastery in Osor, Croatia. This paper examines the dietary significance of edible land snail and marine shell based on extensive taphonomical analyses. In the theoretical part of the paper the interpretation of dietary restrictions in regard to the Rule of St. Benedict and specifically its interpretation by the monks of St. Peter's monastery is given. Filtering the results of taphonomical analyses of this indirect evidence for subsistence through theoretical frameworks socially mediated food acquisition and consumption choices of Benedictine monks at St. Peter's monastery are explored.

Keywords: Monastic diet, diet reconstruction, St. Peter's monastery, malacofaunal remains

The monastery of St. Peter is situated in Osor on island Cres, in Northern Adriatic Quarner Bay, on a somewhat elevated ground in the northern part of the town. The site has been systematically excavated since 2006, though first excavations took place during the 1950 s but these were limited in range ${ }^{1}$. During this past decade, the research conducted by University of Zagreb and French national center for research (CNRS), revealed many important stratigraphic layers of the monastery, its architecture and the church, which added to interpretation of its importance. The first mentioning of the monastery in historical sources dates to the first half of $11^{\text {th }}$ century, which is confirmed by the onsite research. This was an important sacral focal point in a political sense for the wider region.

This is a complex multi period site, and not all of the horizons are associated with monastic activities. This paper is strictly concerned with mollusks shells found on site that present remains of monastic diet. Both land snail and seashell remains were found in abundance, though seashells prevail. Monastic layers at St. Peter's are dated to the $11^{\text {th }}$ century and $12^{\text {th }}$ century ${ }^{2}$. Shell remains were found in midden-like layers containing charcoal, ash, and food refuse in form of shells and animal bones.

\section{SPECIES AND HABITATS}

Mollusk assemblage from monastic layers of St. Peter consists of shells of several marine species that dwell on two different habitats and one genus of land snails dwelling in various habitats. Marine species present in the assemblage all come from the littoral zone, with slight variations in the substrates they dwell on. Murex trunculus, Bolinus brandaris and Cerithium vulgatum dwell on both rocky and sandy substrates. Ostrea edulis, Patella caerulea, Patella vulgata, Monodonta turbinata, Gibula albida and Spondylus gaederopus dwell on rocky bottoms. Cerastoderma edulis occurs on sandy and muddy substrates. On the other hand, Helicidae is a family of land snail of which genus Helix is the most

\footnotetext{
${ }^{1}$ For early research: A. MOHOROVIČIĆ, Pregled i analiza novootkrivenih objekata historijske arhitekture na području grada Osora, in Bulletin Instituta za likovne umjetnosti VII odjela, 1, 2, 1953. For recent research: S. BULLY, M. JURKOVIĆ, M. ČAUŠEVIĆ-BULLY, I. MARIĆ with a contribution by I. PACTAT, Le monastère Saint-Pierre d'Osor (île de Cres): neuvième campagne d'études archéologiques, in Hortus Artium Medievalium (= HAM), 21, Zagreb, 2015, p. 356-365; M. ČAUŠEVIĆ-BULLY, S. BULLY, M. JURKOVIĆ, I. MARIĆ, I. PACTAT, Monastère Saint-Pierre d'Osor (Croatie, île de Cres). Bilan de la mission franco-croate 2014, in Chronique des activités archéologiques de l'École française de Rome, 2015, cfr. http://cefr.revues.org/75; ID., Monastère Saint-Pierre d'Osor (Croatie, île de Cres): bilan de la mission franco-croate 2013, in Chroniques archéologiques de l'École française de Rome, Rome, 2013, en ligne à partir de janvier 2014 http://cefr.revues.org/1046; ID., Le monastère Saint-Pierre d'Osor (île de Cres): septième campagne d'études archéologiques, in HAM, 19, Zagreb, 2013, p. 335-350; ID., Le monastère Saint-Pierre d'Osor (île de Cres): cinquième campagne d'études archéologiques, in Bulletin du Centre d'études médiévales d'Auxerre (= BUCEMA), 15, Auxerre, 2011, p. 103-112; ID., Le monastère Saint-Pierre d'Osor (île de Cres): troisième campagne d'études archéologiques, in HAM, 15, 2, Zagreb, 2009, p. 377-392; ID., Le monastère Saint-Pierre d'Osor (île de Cres): seconde campagne d'études archéologiques, in HAM, 14, Zagreb, 2008, p. 293-306; S. BULLY, M. JURKOVIĆ, M. ČAUŠEVIĆ-BULLY, I. MARIĆ, Benedktinska opatija Sv. Petra u Osoru - arheološka istraživanja 20o62013, in Istraživanja na otocima, in HAM, 30, Zagreb, 2015, p. 103-127; ID., Le monastère Saint-Pierre d'Osor (île de Cres, Croatie), in BUCEMA, 12, 2008, p. 69-77, cfr. http://cem.revues.org/document6282.html; ID., L'église du monastère Saint-Pierre d'Osor (île de Cres): première campagne d'étude, in HAM, 13, 2, Zagreb, 2007, p. 441-456; M. JURKOVIĆ, M. ČAUŠEVIĆ-BULLY, I. MARIĆ, S. BULLY, Le monastère Saint-Pierre d'Osor (île de Cres): sixième campagne d'études archéologiques, in HAM, 18, 2, Zagreb, 2012, p. 459-476; ID., L'ancienne église abbatiale Saint-Pierre d'Osor (île de Cres-Croatie), in BUCEMA, 11, Auxerre, 2007, p. 57-63, cfr. http://cem.revues.org/document1227.html; I. MARIĆ, S. BULLY, M. JURKOVIĆ, M. ČAUŠEVIĆ-BULLY, Le monastère SaintPierre d'Osor (île de Cres): quatrième campagne d'études archéologiques, in HAM, 16, Zagreb, 2010, p. 277-291; ID., Le monastère Saint-Pierre d'Osor (île de Cres, Croatie), in BUCEMA, 13, Auxerre, 2009, p. 67-72, cfr. http://cem.revues.org/index11291.html.

${ }^{2}$ Cfr. n. 1.
} 
common one, well dispersed throughout the Mediterranean. Members of this genus dwell in a broad variety of habitats usually in dry vegetation, mainly in coastal vicinity, also in agricultural crops ${ }^{3}$.

All of these habitats are found in the vicinity of St. Peter. Osor is situated on a narrow strip of land on the very end of island Cres. The coast in the south is sandy, muddy and shallow but the one in the north is rocky. Therefore, it is uniquely positioned which enables gathering of different kinds of sea shell.

\section{METHODOLOGY USED FOR SPECIE DETERMINATION AND QUANTIFICATION}

Specimens from the assemblage were sorted and determined as particular genus and/or specie, counted and examined for traces of manipulation. Some shells remained whole but others were shattered and only fragments remained. The assemblage consists of gastropods and bivalves so the quantification of each requires a somewhat different approach. The quantification was done using Minimum number of individuals. The method is diversely accepted among authors but prior experience proved it to be very useful when analyzing simple and small assemblages without intention to calculate and derive complex information ${ }^{4}$. When assessing the minimum number of individuals for gastropods the whole specimens were counted. When quantifying bivalves the whole specimens were counted but the minimum number of individuals is considered the total number of valves divided by two. In case of oysters whichever of the right or left valve totals is higher (left and right valves in oysters are distinct) was considered to be the minimum number of individuals. Fragments were taken in account only if the apex (in case of gastropods) or the hinge on the valve (in case of bivalves) was present (fig. 1).

Taphonomic analyses were conducted to reveal traces of manipulation i.e. preparation. Traces found on shells from St. Peter's assemblage were then compared to traces recorded on shells that underwent experiments in order to reveal the method of preparation ${ }^{5}$. The traces of burning found in shells after the experiments were conducted are consistent with traces of burning on shells from the assemblage. Experimentation and taphonomic data suggest that shells were opened by heat and not by cooking in a vessel. It is more likely, and firmly supported by evidence that shells were prepared i.e. cooked by an open fire, in a hearth or fireplace. As supported by experimentation, cooking mollusks in a vessel leaves no trace on shells but cooking them by the fire - placing them in ambers of a fire or on a heated surface right next to the fire leaves traces of burning that are later apparent on the shell. It is important to mention

\begin{tabular}{|l|c|c|c|}
\hline \multicolumn{1}{|c|}{ SPECIE } & MNI & fragments & TOTAL no. \\
\hline Helix sp. & 2 & - & 2 \\
\hline Ostrea edulis & 35 & 13 & 47 \\
\hline Patella caerulea & 191 & - & 191 \\
\hline Patella rustica & 97 & - & 97 \\
\hline Monodonta turbinata & 108 & 1 & 109 \\
\hline Gibulla albida & 1 & - & 1 \\
\hline Cerastoderma edulis & 16 & 4 & 21 \\
\hline Murex trunculus & 11 & 3 & 13 \\
\hline Bolinus brandaris & 3 & - & 3 \\
\hline Cerithium vulgatum & 15 & - & 15 \\
\hline Pecten jacobeus & 1 & 1 & 1 \\
\hline $\begin{array}{l}\text { Spondylus } \\
\text { gaederopus }\end{array}$ & 4 & - & 4 \\
\hline Pinna nobilis & 1 & 1 & 1 \\
\hline TOTAL & 485 & 23 & 505 \\
\hline
\end{tabular}

Figure 1.: Species found in monastic layers of St. Peter's with MNI and total numbers

that if prepared with caution, no burns appear on shells whatsoever. This is generally the reason why not all of the shells bare traces of burning. Also, in case of throwing an empty shell in the fire after the consumption causes it to quickly deteriorate therefore traces of burning found can only be interpreted as remains of preparation.

In this assemblage, the total number of burnt specimens is 426 , which is $84,356 \%$ of the assemblage. When looking at a specific specie, traces of fire or burning were found in $59,6 \%$ of Ostrea edulis, 53,3\% of Cerithium vulgate, $96,33 \%$ of Monodonta turbinata, $100 \%$ of Gibulla albida, $61,9 \%$ of Cerastoderma edulis, $66,7 \%$ of Bolinus brandaris, 53,85\% of Murex trunculus, $89,7 \%$ of Patella vulgate and 91,1\% of Patella caerulea (fig. 2).

Following this line of evidence it can be concluded that kitchen in the monastery of St. Peter was equipped with some kind of open fire place. As suggested by finds in contemporary Italian monasteries, the fire place could have been a simple pit in the ground with a chain of rocks surrounding it or a kind of an elevated open fire place ${ }^{6}$. No remains of a kitchen or a fire place were found on site.

\footnotetext{
3 J. LELLAK, Coquillage - atlas illustre, Gründ, 1975; I. JARDAS, Ribe i glavonošci Jadranskoga mora, Sarajevo, 1997; G. AVAGNINA, B. RAĐA, Sve o puževima - jestivi kopneni puževi, Split, 2000.

${ }^{4}$ C. CLAASSEN, Quantifying Shell, in American Antiquity 65, 200o, 2, p. 415-418; R. MASON, M. L. PETERSON, J. A. TIFFANY, Weighing s. Counting: Measurement eliability and the California School of Midden Analysis, in American Antiquity, 63, 1998, p. 303-324; M. GLASSOW, Weighing vs. Counting Shellfish Remains: A Comment on Mason, Peterson, and Tiffany, in American Antiquity, 65, 2, 2000, p. 407-414.

${ }^{5}$ M. RIZNER, N. VUKOSAVLJEVIĆ, P. MIRACLE, The paleoecological and paleodietary significance of edible land snails (Helix sp.) across the Pleistocene-Holocene transition on the eastern Adriatic coast, in Mesolithic horizons, Proceedings from the 7th international conference on Mesolithic in Europe, Belfast 2005, Belfast 2009; M. RIZNER, Paleodietary significance of land snails and marine shells in Vela spila on island Korčula, monograph chapter, forthcoming, 2013. ${ }^{6}$ E. CIRELLI, La dieta dei monaci. Cultura materiale e alimentazione nei monasteri benedettini tra IX eX secolo, in HAM, 19, 2013, p. 227-240; G. ARCHETTI, "Mensura victus constituere". Il cibo dei monaci tra Oriente ed Occidente, in L'alimentazione nell'alto medioevo: pratiche, simboli, ideologie, Sessantatreesima settimana di studio (Spoleto, 9-14 aprile 2015), Spoleto, 2016, p. 757-797; ID., I monaci a tavola: norme e consuetudini alimentari, in L Pani Ermini (a cura di), Gli spazi della vita comunitaria, Atti del convegno internazionale (Roma-Subiaco, 8-10 giugno 2015), Spoleto, 2016 (De re monastica, 5), pp. 305-327.
} 


\begin{tabular}{|l|c|}
\hline \multicolumn{1}{|c|}{ SPECIE } & $\begin{array}{c}\text { Burnt } \\
\%\end{array}$ \\
\hline Ostrea edulis & 59,6 \\
\hline Patella caerulea & 9,1 \\
\hline Patella rustica & 89,7 \\
\hline Monodonta turbinata & 96,33 \\
\hline Gibulla albida & 100 \\
\hline Cerastoderma edulis & 81,25 \\
\hline Murex trunculus & 53,85 \\
\hline Bolinus brandaris & 69,7 \\
\hline Cerithium vulgatum & 53,3 \\
\hline Spondylus gaederopus & 25 \\
\hline TOTAL & 84,35 \\
\hline
\end{tabular}

Figure 2. Percentages of burnt specimens by specie

\section{THE RULE OF ST. BENEDICT}

Benedictine monks lived by the Rule of St. Benedict which the saint wrote in $540 \mathrm{AD}^{7}$. Short and clear in content, the rule was divided in 73 chapters giving a series of spiritual and practical advices. The rule governed the day of monks: obedience, silence, humbleness as pillars of their life, but it also governed some specific aspects of life. One of which is food, amount of food and wine allowed, time of eating in the day and other eating and drinking habits. These topics are covered in chapters 36,39 and 40 . Particularly interesting part of the rule is the chapter that forbids eating the flesh of quadrupeds (chapter 39) and the chapter that allows eating it to the sick brethren (chapter 36 ). In order to remain healthy and still obey the rule, monks had to eat some form of proteins and shells, containing in an average approximately $20 \%$ of protein and bearing other valuable nutrients (healthy fats, minerals and vitamins), provided both protein intake and obedience of the rule.

\section{CONCLUSION}

Monks at St. Peter's monastery in Osor preferred shells found in rocky littoral zone, the reason for this is unknown at the time. As suggested by the taphonomic evidence compared to experimentation data mollusks eaten at the site were prepared by an open fire. Therefore, the kitchen of St. Peter's monastery was equipped with a sort of open fire place or a simple hearth. When observing the subsistence strategies of monks living in monastery of St. Peter in Osor shells' procuring provides usage of local food source that contribute to the sustainability and independence of the monastery in its landscape.

Eating of mollusks provides obedience of the Rule, regardless of its change through time, and at the same time maintaining a balanced and healthy diet. 